\title{
Upholding the Malay Language and Strengthening the English Language Policy: An Education Reform
}

\author{
Hamidah Yamat ${ }^{1}$, Nur Farita Mustapa $\operatorname{Umar}^{1} \&$ Muhammad Ilyas Mahmood ${ }^{1}$ \\ ${ }^{1}$ Faculty of Education, Universiti Kebangsaan Malaysia, Malaysia \\ Correspondence: Hamidah Yamat, Faculty of Education, Universiti Kebangsaan Malaysia, 43600 UKM Bangi, \\ Selangor, Malaysia. Tel: 601-9283-5027. E-mail: hamidah_yamat@ukm.edu.my
}

Received: July 22, 2014 Accepted: November 5, 2014 Online Published: December 21, 2014

doi:10.5539/ies.v7n13p197

URL: http://dx.doi.org/10.5539/ies.v7n13p197

\begin{abstract}
Today's global economy and dependency on technology has led to educational reforms in Malaysia, which includes language policies; namely the Upholding the Malay Language, and Strengthening the English Language $(M B M M B I)$ policy. This policy underpins the project presented and discussed in this paper; on the development of a bilingual education and assessment framework for higher education providers (HEP). This paper discusses the analysis of documents on the language planning and its implementation policies at three HEPs; namely Universiti Kebangsaan Malaysia (UKM), Universtiti Teknologi Mara (UiTM) and Universiti Kuala Lumpur (UniKL) as well as the Malaysian Education Blueprint 2013-2025. Findings of the comparative analysis indicate that each university interprets bilingual policy differently thus implement it differently which in return resulted in different language abilities among their graduates. This also implies the vital need for a clear framework on bilingual education as well as its assessment in order for the education reform to be successful in its aim to strengthen the English language competency and at the same time uphold the Malay language among its nation.
\end{abstract}

Keywords: education reform, language policy, strengthening the English language, upholding the Malay language

\section{Introduction}

Language planning has been conceived as an effort, usually at national level, to change language behaviour of some population for some stated or implied reasons (Kaplan \& Baldauf, 2008). According to Kloss (1969 in Cooper, 1989), language planning focuses on corpus planning and status planning. Corpus planning refers to the creation of new forms, the modification of old ones, or the selection from alternative forms in a spoken or written code while the object of status planning is the recognition by a national government of the importance or position of one language in relation to others (Cooper, 1989).

Generally, language planning represents a coherent effort by individuals, groups, or organizations to influence language use or development (Robinson, 1998). Language planning plays a vital role in any country, more so in a multilingual country like Malaysia. For example, there is a situation where a number of linguistic groups compete for access to the mechanisms of day-to-day life including education. Thus, both governmental and educational institutions must effectively and equitably meet the needs of the population so that groups varied in linguistic repertoire have an equal opportunity to participate in their government and to receive services from their government. Language planning decisions typically attempt to meet these needs by reducing linguistic diversity, as in instances where a single language is declared a national language in a multilingual country. For instance in Malaysia, Bahasa Melayu or the Malay language has been declared the national and official language while English is an official language or where a single variety of a language is declared "standard" to promote linguistic unity in a country where divergent dialects will exist.

However, in today's global economy, the success of any country; including a developing country such as Malaysia; depends on the knowledge, skills and competencies of its nation. This has led the Malaysian government to take various economic measures such as the 1st Malayan Plan to the 9th Malaysian Plan, New Economic Policy, National Development Policy, and the National Vision Policy in the attempt to increase the nation's socioeconomic status. As a result, the nation's income index shows that the per capita income increased from RM13,939 in the year 2000 to RM26,175 in the year 2010 (Laporan Kualiti Hidup Malaysia, 2011). Nevertheless, the poverty rate has not been reduced because development is not just a process in which the poor 
becomes rich but also the rich becomes richer (ibid, 2011). Thus, the Malaysian government feels that there is a need for educational transformation because education plays a significant role in the economic growth and development of a country.

In line with that, the 2013-2025 Education Development Plan (Pelan Pembangunan Pendidikan, 2012) outlines several measures to be taken in this education transformation effort. One of the measures is related to the use of language in the teaching and learning process. Language policy and planning can assist efforts to change a state and society in radical ways as language planning is an important instrument of revolutionaries change. In this context, as Malaysia has a heritage of various ethnic groups and cultures, the Malay language is the national language used by all while the Chinese, Indians and other ethnic minorities maintain the knowledge of their mother tongue as well as use them actively (Tan, 2005). Meanwhile, English language is widely used in both social and professional purposes. This situation enables Malaysia to have its people skilled in more than one language. This is the Malaysian identity that needs to be illuminated; that Malaysians are multilingual - their mother tongue, the Malay language and the English language. However, their competencies in the languages vary. This implies that the Upholding the Malay Language and Strengthening the English Language policy $(M B M M B I)$ is an effort that needs to be heightened.

In doing so, there is a need to understand what bilingual education pertains. According to Krashen (1999), it is helpful to distinguish two goals of bilingual education, which are the development of academic English and school success, and the second is the development of the heritage language. Good bilingual education programmes achieve both goals through the proper and calculated implementation of the policy. The main purpose of having the bilingual policy is to enable learners to master two languages namely Malay and their official language. English is given a lot of importance as the proficiency in English enables the child to access a greater mass of information in this globalized world (Ministry of Education, 2008). Undeniably, globalization has brought about unprecedented spread of English (Zuraidah, Farida, Haijon, Chuah, \& Katsuhiro, 2011). As such, the students will be able to benefit greatly from learning two languages through the bilingual policy. Hence, the bilingual policy is a way to be parallel with not only modernization but also globalization in general.

\section{Literature-The MBMMBI policy and the Common European Framework of Reference (CEFR)}

The MBMMBI policy is addressed to students at both schools and higher education providers (HEP). It is particularly a serious concern at HEPs as it is related to the marketability or employability of Malaysian graduates where many studies have shown that one of the main source of unemployability among them (particularly when being interviewed for the first time) is failure to communicate in English and Malay (Nik, Azmi, Rusyda, Arena, \& Khairani, 2012).

The Malaysian Education Plan (Pelan Pembangunan Pendidikan Malaysia, 2012) also indicates the initiative to align the Malay language as well as English language curriculum and assessment along the Common European Framework of Reference for Languages (CEFR); that is utilizing CEFR scales as benchmarks for all languages. In the words of the Plan, Malaysian students are expected to achieve the 'operational proficiency' level defined by the CEFR as the linguistic fluency required for full participation in professional and academic life. This 'bilingual proficiency' is one of the six key attributes needed by every student to be globally competitive (ibid, 2012). The CEFR "provides a common basis for the elaboration of language syllabuses, curriculum guidelines, examinations, textbooks, etc. across Europe. It describes in a comprehensive way what language learners have to learn to do in order to use a language for communication and what knowledge and skills they have to develop to be able to act effectively. The description also covers the cultural context in which language is set. The framework also defines the proficiency levels that allow learners' progress to be measured at each stage of learning and on a life-long basis" (Council of Europe, 2001, p. 1). The CEFR "is now accepted as the international standard for language teaching and learning" (North, Ortega, \& Sheehan, 2010, p. 6), and its influence is spreading across and beyond Europe. It should be noted, however, that the CEFR is a language-independent framework, in which an action-oriented approach is adopted.

The CEFR (Council of Europe, 2001) has been gaining much attention these days not only in Europe but also in the rest of the world, as a generic framework of language proficiency for teaching, learning and assessment. It provides comprehensive views of what people can do with language, and seems to be very useful in setting truly communicative, functional goals for learners. As Malaysia is very rapidly internationalizing, particularly in the field of education; Malaysia Ministry of Education has taken the decision of involving CEFR in language education, mainly to scale its students' language abilities against globally acknowledged levels. According to Figueras (2012), two features of the CEFR most widely and promptly used are: a) the CEFR reference level labels that are $\mathrm{A} 1, \mathrm{~A} 2, \mathrm{~B} 1, \mathrm{~B} 2, \mathrm{C} 1, \mathrm{C} 2 ; \mathrm{b})$ the CEFR reference level descriptors, influencing widely on 
developing of language learning objectives and outcomes in different contexts.

An analysis of the CEFR indicates that that CEFR does not aim to guide practitioners as to how to lay down objectives and choose appropriate methods and strategies according to their particular contexts (North, 2004). The study finds CEFR as a flexible tool to facilitate reflection, communication and networking. In other words, it can be adapted to allow its use in a large number of contexts according to the particular needs of that context, but at the same time, adhering to the main principles of the common framework. Today, the CEFR level labels are commonly used in Europe for all educational levels by various stakeholders (Figueras, 2012). Basically, the CEFR was developed for foreign language learning, but now also being widely used for L1. Martyniuk and Noijons (2007) identify that it is also being followed in teaching languages for specific purposes. Established private language centres round the world, including in non-European countries are describing the results of the language learners aligned with the CEFR levels than interpreting their performance only as Beginner, Intermediate, or Advanced.

Similarly, Malaysia's Ministry of Education is to employ CEFR as the framework in relation to the MBMMBI policy (Malaysia Education Plan, 2013-2025). However, CEFR only provides a guideline for interpreting students' language ability. There is a need for a clear framework on the education and assessment of bilingual education; of using both the Malay and English languages in the teaching and learning process at schools and HEPs and assessing students' achievement. This framework can then be employed as a guideline in the planning and implementation of bilingual activities that can increase the values of our graduates. Hence, a framework for Bilingual Education and Assessment needs to be developed. It is this need and purpose that led to the project discussed in this paper. This study is also significant as it is related to the graduate employability which is important in the development of a nation (Zaini, Juriah, Zarin, \& Khalid, 2008) as there are about 180,000 Malaysian graduates with either a Diploma or Degree every year (Pelan Pembangunan Pendidikan Malaysia, 2012). Sadly however, the report on Graduate Tracers Study 2009 carried out by the Ministry of Education showed that in the first three months upon graduation, only 81,744 or $52.7 \%$ of our graduates were employed in comparison to the 41,514 or $26.7 \%$ who were still unemployed (Mohamed, 2010).

\section{Method}

This study employs a mixed-method research design, which involves the use of questionnaire, interviews and document analysis for data collection and the Delphi technique. The four phases of the project involve: 1) Analysing the Common European Framework (CEFR) for the elaboration of the English language as well as the policy on the use of the Malay and English languages and its implementation at UKM, UiTM and UniKL; 2) Identifying the language aspects and language use aspects for both the mother tongue and the second/foreign language among 300 students at UKM, UiTM and UniKL. Questionnaire and interviews will be carried out to gather this data; 3) Developing the framework for bilingual education and assessment based on the data gathered in the first and second phases; and 4) Evaluating the framework developed through the Delphi Technique; involving experts in the fields. This paper reports the findings of the first phase that is document analysis of the CEFR and HEPs' policy/documents on the use of the Malay and English languages.

Three institutions were purposively chosen based on the general understanding of the foundations of the institutions. First, UKM was chosen because it was founded in 1970 from the aspirations of the nationalists to uphold the Malay language as a language of knowledge. This means that the medium of instruction in UKM is the Malay language. Meanwhile, UiTM started as a MARA Institute of Technology in 1967 as a response to the need for trained professionals particularly among the Bumiputras (the Malays). It was conferred as a university; carrying the name UiTM in 1996. As the aim of UiTM is to produce professionals, the language used as a medium of instruction is mostly English. Finally, UniKL is a multi-campus university was established in 2002 as an engineering technology private university. UniKL aims at moulding its graduate with strong technological knowledge and astute entrepreneurial skills who would later fulfil the current demand of the industries. This explains why the medium of instruction at UniKL is English language.

\section{Findings and Discussions}

In general, education policies regarding English language teaching in Malaysia has undergone a number of radical changes but not for Bahasa Melayu. According to Malaysian constitution, in Article 152, Bahasa Melayu is the national language and it has not changed until now. Moreover, the role of Bahasa Melayu is further emphasised in the 'Dasar Pendidikan Kebangsaan' whereby Bahasa Melayu is used as the medium of instructions. Most of the public universities use Malay as medium of instruction except for some courses especially science and technology, they are taught in English. One of the UKM's missions is to be the learning centre of choice that promotes the sovereignty of Bahasa Melayu and this university is built based on the 
constitution of Malaysia (Penerbit UKM, 2010).

In contrast, the private universities still use English as the medium of instruction. There is no enforcement of the national language act in the private sector because the government realises that for the educational sector to flourish, freedom with regard to the medium of instruction policy has to be given. As stated in Article 152, the Constitution guarantees the freedom of learning and using of other languages, except on official purposes. As a result of the above education policies, two higher education streams have emerged - public universities where undergraduates study in Malay and private institution of higher learning where instructions are provided in English (Ales Puteh, 2010). In UniKL, the medium of instruction is English and this is parallel to the university's mission which is to produce enterprising global technopreneurs whereby students have to be proficient in English because if they are not, then employers will face problem hiring them; as generally local graduates are highly qualified but are not proficient in English (Ministry of Higher Education, 2012).

The freedom given by the government also allows other public universities like UiTM to use English as the medium of instruction. This is in line with UiTM's mission to enhance the knowledge and expertise of Bumiputras in all fields of study through professional programmes, research work, and community service based on moral values and professional ethics. This mission can only be achieved if they use English as the medium of instruction because English is an indispensable tool that helps students achieve the 21st century aspiration. Fluency in English enables the students to prevail against many challenges posed by the effects of globalization and they have to accept that English is a global language (Musa, 2003).

Besides that, the significance of the policy can also be seen through the medium of instruction, as it is the most powerful means of maintaining and revitalizing a language and a culture and form of intergenerational transmission (Fishman \& Fishman, 2000 in Tollefson \& Tsui, 2004). In view of that, private universities such as UniKL, the practical or instrumental nature of choosing English as the medium of instruction affirm that this choice of language is objective. These private universities firmly believe in the objective nature of this language in education policy and are convinced that mother tongue is not an appropriate medium of instruction (Gupta, 1997 in Vaish \& Teck, 2008). Thus, bilingualism did not mean learning any two languages. Rather, it means an English-plus policy; English as the dominant language with a second language as a minor language (Gurdial, 2008).

As for public universities, UKM for example, their policy prioritizes the use of the Malay language as the official national language and the medium of instruction. For most students, the English language may be their second or third language and hence, some may have difficulties in coping with the lessons. Children with mother tongue other than Malay need to develop their fluency in their own mother tongue prior to acquiring competency in their second language, that is, Bahasa Melayu This is to enable them to transfer successfully the language acquisition skills necessary to acquiring fluency in the English language at a later stage in their education. These students usually encounter literacy problems, which directly impacts on their learning progress (Ministry of Education, 2008). This implies that the medium of instruction hinders the process of the students becoming successful bilinguals as intended by the language planning.

In some universities, their language policy satisfies a number of factors that have been identified as necessary for successful implementation of a bilingual education programme. The most important language, in this context the Malay is established and is perceived to have as much as prestige, through often in different domains, as the L2 (English). This policy is adapted in most public or private universities in Malaysia. The advantages of becoming bilingual go beyond immediate educational and economic considerations, and this message needs to be properly spread to the whole community.

A summary of the findings discussed is shown in Table A on the Comparative Analysis of University Policies on Language Use (Appendix A). It summarizes UKM, UiTM and UniKL's interpretation and implementation on the use of the Malay and English languages. In all these three universities, the local students are required to attain a credit in Bahasa Melayu at SPM level and at least Band 1 in MUET. This means that both languages are important because students have to fulfil these requirements if they want to study in these universities. However, for the international students who want to study in UKM or UiTM, they have to fulfil the entry requirement of the university by obtaining a minimum score of 550 for TOEFL or a band 5 for IELTS differ from UniKL which requires only students whose mother tongue is not English to provide either one of the following; IELTS band 5.5 minimum, TOEFL score 525 minimum and they have their own English Placement Test (EPT) band 5.5 minimum. UKM also makes it compulsory for all (non-Malaysian) candidates to complete two courses of "Bahasa Melayu for Academic Purposes", whereby exemption is given only for those who have undergone similar courses in Bahasa Melayu (Universities and University Colleges Act 1971, 2006; UKM Constitution 
UKM Rules, 2010). These international students have to complete two courses, as this is one the requirements for them to graduate.

In addition, the value of a language is its usefulness as English is the key language for people to make a living whereby multinational companies use English and it gives us easy access to English-speaking societies and the developed world (Teh, 2009). This is the reason why private Universities have chosen English language as part of their bilingual policy. It is also a clear indication of how these private universities see English as a tool of being inclusive in students' future success. In fact, these private universities need to struggle to be connected to the larger multinational companies that use English as their means to communicate in the business world.

In the case of UiTM, although it is a public university, the importance of English can be seen when its medium of instruction is English and most of the activities are conducted in that language as to promote fluency. This indirectly enhances students' communication skills and develops soft skills, which are crucial for their future as currently deficiencies are seen in the areas of communication, ICT knowledge, and professional and technical skills which have resulted in an insufficient supply of employable graduates (Ministry of Higher Education, 2012).

The reality is that the end result of the bilingual policy is not immediate. In fact, it takes some time to achieve it as Adeelar and Himmelmann (2005) pointed out that the intended result of bilingual education is that graduates of secondary education retained Malay as their first language, while acquiring a high degree of proficiency in English as a second language. In other words, for the policy to be successful; time is needed and most likely instant intended results cannot be achieved. That is why all the activities in UniKL are done in English as to increase students' proficiency even though time is needed for them to do so. This is because the reason given is that English is the language of wider communication, and in order to tap into current knowledge, knowledge of English is necessary (Tan, 2005). Furthermore, students need access to multicultural environment, appropriate use of first language and use of effective English method in content instruction as well as opportunity to show their competence in a variety of ways. The Minister of Education, Musa (2003) suggests that it is possible just to emphasise what Halliday (1975) calls the pragmatic (language-as-action) and mathetic (language-for-learning) functions of language almost to the exclusion of others when he says, "we cannot help but acknowledge the instrumental role of the English language'. 'Instrumental function' refers to how English can allow us to access information (mathetic function) and perhaps get on in life (pragmatic function), but without affecting the Malaysian's inner psyche, outlook or culture.

Besides that, the development of language plans has tended to reflect political and economic imperatives of particular social groups rather than what could be construed as linguistic or cultural concerns per se (Baldauf, 1994). As such, significance from the aspect of economy is indubitable since an increasing number of specialists in language issues have come to realize that the type of policies they often advocate have economic implication. The more people use it, the more valuable it becomes, as a tool for communication, to people who already use it (Grin, 2006) and it could bring immense benefits in terms of economic development (Gurdial, 2008). These can definitely be seen as the driving force behind the choice of using English in the bilingual policy implemented by the universities in Malaysia such as UiTM and UniKL. For instance, according to Tollefson and Tsui (2004), the high economic value of English has led to a language shift whereby English is the predominant language both at home and in the community, especially among the younger generation.

\section{Conclusion}

A language policy like the bilingual policy reflects the importance given to the English language since an economical value has been attached to it. In sum, education serves the socio-political and economic interests that can perpetuate and enhance power (Ricento \& Hornberger, 1996) as can be seen in those particular countries. Although Bahasa Malaysia has become by law the official language, the practical status of this language is still not fully realized. This language still gives way to English (Ales, 2010). This is due to many factors such as a tertiary student is not assured of a place in the private sector if he or she does not have a good grasp of English. A Malay student with no knowledge of Mandarin will have no chance in getting a job in Chinese firms, which usually take workers from their own ethnic groups, and usually members of their own family. A national language is seen as essential for national unity and English is seen as the language of modernisation, knowledge transfer and international communication (Kirkpatrick, 2009). Thus, having the bilingual policy is important as it is said to be able to prepare the students to face globalization.

The higher education institutions in Malaysia such as UKM, UiTm and UniKL practice bilingual policy as suggested in Malaysian Constitution. The implementation of the policy differs for these three universities depend on their vision and mission but still the impact is the same in helping the students to cope with the challenges of 
the 21st century. To conclude, bilingualism has been essential for the harmonious relations among the various ethnic groups (Shepherd, 2003 in Gurdial, 2008) in tertiary educational universities. The different language planning and implementation of the bilingual policy in the foresaid universities has brought about distinctive end results. Without exception, Ministries of Education has decided that Bahasa Melayu is important in building up nation and English is a vital skill that must be learned by their citizens from as early an age as possible, if their respective countries are to modernise and to be able to participate in today's globalised world (Kirkpatrick, 2009).

\section{Acknowledgements}

This is a part of the project under the Ministry's Fundamental Research Grant Scheme (FRGS/1/2013/SSI09/UKM/02/1.

\section{References}

Adeelar, K. A., \& Himmelmann, N. (2005). The Austronesian languages of Asia and Madagascar. London and New York: Routledge.

Ales, P. (2010). The language medium policy in Malaysia: A plural society model? Review of European Studies, 2(2).

Baldauf, R. B. J. (1994). Unplanned language policy and planning. Annual Review of Applied Linguistics, 14, 82-89.

Cooper, R. L. (1989). Language Planning and Social Change. http://dx.doi.org/10.1017/CBO9780511620812

Council of Europe. (2001). Common European framework of reference for languages. Language Policy Unit, Strasbourg. Retrieved from http://www.coe.int/lang-CEFR

Figueras, N. (2012). The Impact of the CEFR. ELT Journal, 66(4), 477-485.

Grin, F. (2006). Economic considerations in language policy. In T. Ricento (Ed.), An introduction language policy. Theory and method. Malden, MA: Blackwell.

Gurdial, K. (2008). Teachers' and Pupils' Perception of the Effectiveness of non-Tamil Indian Languages (NTIL) Policy in Singapore (Master thesis, University of Western Australia). Retrieved from http://www.hci.sg/admin/uwa

Halliday, M. A. K. (1975). Learning how to mean: Explorations in the development of language. New York: Elsevier.

Kaplan, R. B., \& Baldauf, R. B. (2008). Encyclopedia of Language and Education. Hornberger, N. H. An Ecology Perspective on Language Planning. Springer US. Retrieved from http://www.springerlink.com/content/g0j2181601014436/

Kirkpatrick, A. (2009). Learning English and other languages in multilingual settings: myths and principles. Retrieved from http://libir1.ied.edu.hk/pubdata/ir/link/pub/9917.pdf

Krashen, S. D. (1999). Condemned Without A Trial: Bogus Arguments Against Bilingual Education. NH: Heinemann.

Laporan Kualiti Hidup Malaysia. (2011). Unit Perancangan Ekonomi, Putrajaya: Jabatan Perdana Menteri, learning, teaching, and assessment. Cambridge: Cambridge University Press.

Martyniuk, W., \& Noijons, J. (2007). Executive Summary of Results of a Survey on the Use of the CEFR at National National Level in the Council of Europe Member States. Retrieved from $\mathrm{http} / / / \mathrm{www} . c o e . i n t / \mathrm{t} / \mathrm{dg} 4 /$ linguistic/source/survey_CEFR_2007_EN.doc

Ministry of Education. (2008). The Development of Education Ministry of Education 2008. Retrieved from http://www.ibe.unesco.org/National_Reports/ICE_2008/brunei_NR08.pdf

Ministry of Higher Education. (2012). The National Graduate employability Blueprint 2012- 2017. Serdang: Universiti Putra Malaysia Press.

Mohamed, K. N. (2010). Latihan industri pastikan graduan miliki kebolehpasaran. Kuala Lumpur: Ministry of Higher Education.

Musa, M. (2003). Teaching Science and Mathematics in English: The Way Forward. The ELTC ETeMS Conference Proceeding. Retrieved from http://unistar.wordpress.com/tag/ppsmi/

Nagai, N. (2010). Sogo eigo puroguramu no zengakudonyu to aratanaru chosen [Implementation of integrated 
english program; A new challenge]. In N. Yamagishi, S. Takahashi, \& M. Suzuki (Eds.), English Language course design (pp. 219-237). Tokyo: Taishukan.

Nagai, N., \& O'Dwyer, F. (2011). The actual and potential impacts of the CEFR on language education in Japan. Synergies Europe, 2011, 141-152.

Nik, H. O., Azmi, A. M., Rusyda, H. M., Arena, C. K., \& Khairani, A. A. (2012). Graduates' employability skills based on current job demand through electronic advertisement. Asian Social Science Journal, 8(9).

North, B. (2004). Europe's framework promotes language discussion, not directives. Guardian Weekly. Thursday 15 April. Retrieved from http://www.guardian.co.uk/education/2004/apr/15/

North, B., Ortega, A., \& Sheehan, S. (2010). A core inventory for general English, British Council/EAQUALS. Retrieved from http://www.teachingenglish.org.uk/sites/teaching/files

Pelan Pembangunan Pendidikan Malaysia 2013-2025. (2012). Putrajaya: Kementerian Pendidikan Malaysia.

Penerbit UKM. (2010). Universiti Kebangsaan Malaysia universiti untuk nagara titah perdana DYMM Tuanku Canselor sempena sambutan 40 tahun UKM. Bangi: Penerbit UKM.

Ricento, T. K., \& Hornberger, N. H. (1996). Unpeeling the Onion: Language Planning and Policy and the ELT Professional. TESOL Quarterly, 30(3), 401-427. Retrieved from http://biblioteca.uqroo.mx/hemeroteca/tesol_quartely/1967_2002_fulltext/Vol_30_3.pdf\#

Robinson, D. (1998). Language Policy and Planning. ERIC Digest. Retrieved from http://www.ericdigests.org/pre-9210/planning.htm

Tan, K. W. (2005). The medium-of-instruction debate in Malaysia English as a Malaysian language? Language Problems \& Language Planning. Retrieved from http://www.factworld.info/malaysia/news/debate.pdf

Teh, S. N. (2009). Learn Mandarin to connect with China: MM Lee. Business Times 18 March 2009. Retrieved from http://app.mfa.gov.sg/pr/read_content.asp?View,12370

Tollefson, J. W., \& Tsui, A. (Eds.) (2004). Medium of Instruction Policies: Which Agenda? Whose Agenda? Mahwah, NJ: Lawrence Earlbaum.

UKM Constitution UKM Rules. (2010). UKM: Penerbit UKM.

Universities and University Colleges Act 1971. (2006). Retrieved from http://www.agc.gov.my/Akta/Vol.\%201/Act\%2014.pdf

Vaish, V., \& Teck, K. T. (2008). Language and Social Class: Linguistic Capital in Singapore. Retrieved from http://repository.nie.edu.sg/jspui/bitstream/10497/1697/3/HoKaiFai.htm

Zaini, M., Juriah, L., Zarin, I., \& Khalid, A. (2008). Isu Pengangguran Siswazah Dan Kemahiran Berkomunikasi: Antara Kecekapan Berbahasa Melayu Dan Inggeris, Mana Satu Keutamaan Majikan? Prosiding Perkem III, Jilid 1, 65-76.

Zuraidah, Z., Farida, I. R., Haijon, G., Chuah, B. L., \& Katsuhiro, U. (2011). Internationalization of Higher Education: A Case Study of Policy Adjustment Strategy in Malaysia. International Journal for Cross-Disciplinary Subjects in Education (IJCDSE), Special Issue, 1(1).

\section{Appendix}

Table A. Comparative analysis of university policies on language use

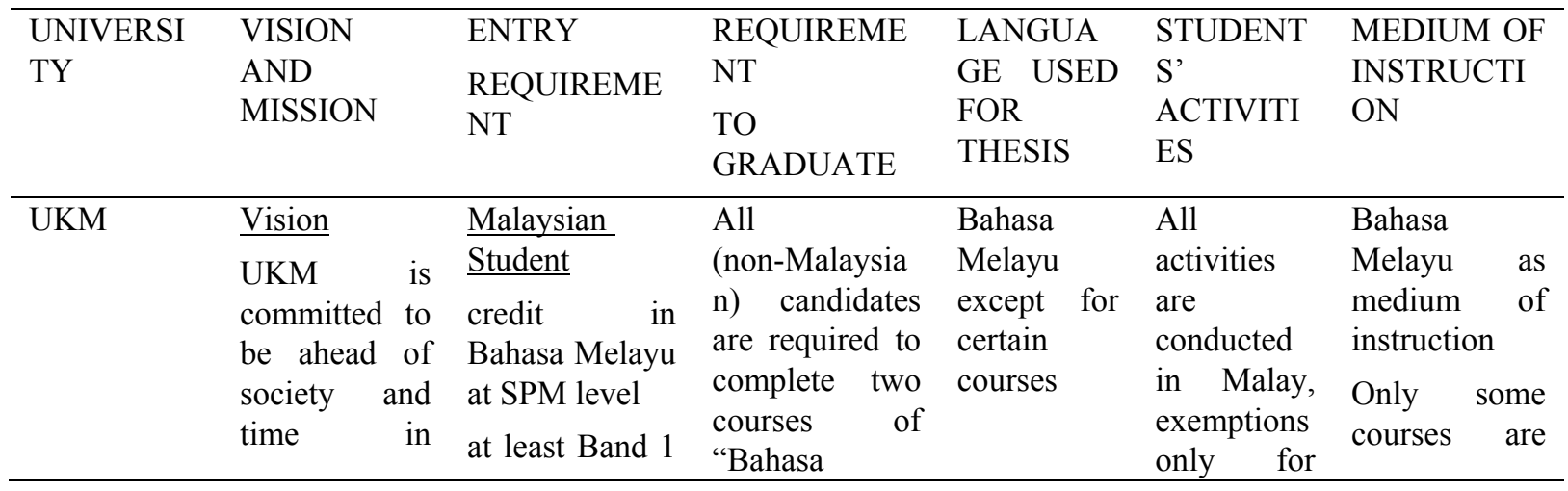




\begin{tabular}{|c|c|c|c|c|c|c|}
\hline & $\begin{array}{l}\text { leading the } \\
\text { development } \\
\text { of a learned, } \\
\text { dynamic and } \\
\text { moral society } \\
\text { Mission } \\
\text { To be the } \\
\text { learning } \\
\text { centre of } \\
\text { choice that } \\
\text { promotes the } \\
\text { sovereignty of } \\
\text { Bahasa } \\
\text { Melayu and } \\
\text { internationali } \\
\text { ses } \\
\text { knowledge } \\
\text { rooted in the } \\
\text { national } \\
\text { culture }\end{array}$ & $\begin{array}{l}\text { in MUET } \\
\text { International } \\
\underline{\text { Student }} \\
\text { obtain } \\
\text { minimum score } \\
\text { of } 550 \text { for } \\
\text { TOEFL or a } \\
\text { band } 5 \text { for } \\
\text { IELTS }\end{array}$ & $\begin{array}{l}\text { Melayu for } \\
\text { Academic } \\
\text { Purposes", } \\
\text { exemptions for } \\
\text { those who have } \\
\text { undergone } \\
\text { similar courses } \\
\text { in Bahasa } \\
\text { Melayu }\end{array}$ & & $\begin{array}{l}\text { certain } \\
\text { activities }\end{array}$ & $\begin{array}{l}\text { taught } \\
\text { English }\end{array}$ \\
\hline UiTM & $\begin{array}{l}\text { Vision } \\
\text { To establish } \\
\text { UiTM as a } \\
\text { premier } \\
\text { university of } \\
\text { out-standing } \\
\text { scholarship } \\
\text { and academic } \\
\text { excellence } \\
\text { capable of } \\
\text { providing } \\
\text { leadership to } \\
\text { Bumiputra's } \\
\text { dynamic } \\
\text { involvement } \\
\text { in all } \\
\text { professional } \\
\text { fields } \\
\text { world-class } \\
\text { standards in } \\
\text { order } \\
\text { produce to } \\
\text { globally } \\
\text { Mission } \\
\text { To enhance } \\
\text { the } \\
\text { knowledge } \\
\text { and expertise } \\
\text { of Bumiputras } \\
\text { in all fields of } \\
\text { study through } \\
\text { professional } \\
\text { programmes, } \\
\text { research }\end{array}$ & $\begin{array}{l}\text { Malaysian } \\
\underline{\text { Student }} \\
\text { credit in } \\
\text { Bahasa Melayu } \\
\text { at SPM level } \\
\text { at least Band 1 } \\
\text { in MUET } \\
\text { International } \\
\text { Student } \\
\text { obtain a } \\
\text { minimum score } \\
\text { of } 550 \text { for } \\
\text { TOEFL or a } \\
\text { band } 5 \text { for } \\
\text { IELTS }\end{array}$ & & $\begin{array}{l}\text { English } \\
\text { except for } \\
\text { certain } \\
\text { courses }\end{array}$ & $\begin{array}{l}\text { Most of the } \\
\text { activities } \\
\text { are } \\
\text { conducted } \\
\text { in English }\end{array}$ & $\begin{array}{l}\text { Bahasa } \\
\text { Malaysia as } \\
\text { medium of } \\
\text { instruction } \\
\text { Only some } \\
\text { courses are } \\
\text { taught in } \\
\text { English }\end{array}$ \\
\hline
\end{tabular}




\begin{tabular}{|c|c|c|c|c|c|}
\hline & $\begin{array}{l}\text { work, and } \\
\text { community } \\
\text { service based } \\
\text { on moral } \\
\text { values and } \\
\text { professional } \\
\text { ethics }\end{array}$ & & & & \\
\hline \multirow[t]{14}{*}{ UniKL } & Vision & Malaysian & \multirow[t]{14}{*}{ English } & \multirow{14}{*}{$\begin{array}{l}\text { All } \\
\text { activities } \\
\text { are } \\
\text { conducted } \\
\text { in English }\end{array}$} & \multirow{14}{*}{$\begin{array}{l}\text { English as } \\
\text { medium of } \\
\text { instruction } \\
\text { Most courses } \\
\text { are taught in } \\
\text { English }\end{array}$} \\
\hline & To become & $\underline{\text { Student }}$ & & & \\
\hline & the premier & credit in & & & \\
\hline & & at SPM level & & & \\
\hline & university & at least Band 1 & & & \\
\hline & $\underline{\text { Mission }}$ & in MUET & & & \\
\hline & \multirow{8}{*}{$\begin{array}{l}\text { To produce } \\
\text { enterprising } \\
\text { global } \\
\text { technopreneu } \\
\text { rs }\end{array}$} & $\underline{\text { International }}$ & & & \\
\hline & & $\begin{array}{l}\text { those whose } \\
\text { mother tongue }\end{array}$ & & & \\
\hline & & $\begin{array}{l}\text { is not English } \\
\text { are required to } \\
\text { provide either }\end{array}$ & & & \\
\hline & & $\begin{array}{l}\text { one of the } \\
\text { following: }\end{array}$ & & & \\
\hline & & $\begin{array}{l}\text { IELTS band } \\
5.5 \mathrm{~min}\end{array}$ & & & \\
\hline & & TOEFL score & & & \\
\hline & & $525 \mathrm{~min}$ & & & \\
\hline & & EPT band 5.5 & & & \\
\hline
\end{tabular}

\section{Copyrights}

Copyright for this article is retained by the author(s), with first publication rights granted to the journal.

This is an open-access article distributed under the terms and conditions of the Creative Commons Attribution license (http://creativecommons.org/licenses/by/3.0/). 